\title{
Development of Molecular Marker through Genome Realignment for Specific Detection of Xanthomonas campestris pv. campestris Race 5, a Pathogen of Black Rot Disease ${ }^{\mathrm{S}}$
}

\author{
Khandker Shazia Afrin ${ }^{\dagger}$, Md Abdur Rahim ${ }^{\dagger}$, Hee-Jeong Jung, Jong-In Park, Hoy-Taek Kim, and Ill-Sup Nou*
}

Department of Horticulture, Sunchon National University, Suncheon 57922, Republic of Korea

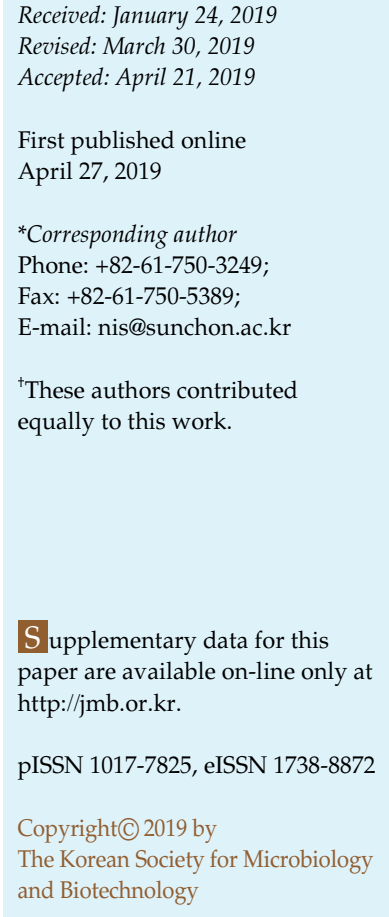

S upplementary data for this paper are available on-line only at http://jmb.or.kr.

pISSN 1017-7825, eISSN 1738-8872

Copyright(C) 2019 by

The Korean Society for Microbiology and Biotechnology

\begin{abstract}
Black rot caused by Xanthomonas campestris pv. campestris (Xcc) is the most damaging disease in Brassica crops around the world. In this study, we developed a molecular marker specific to $X c c$ race 5. To do this, the available whole genome sequences of Xcc races/strains and Xc subspecies were aligned and identified a highly variable genomic region (XccR5-89.2). Subsequently, a primer set covering the 'XccR5-89.2' region was designed and tested against the genomic DNA of Xcc races/strains, Xc subspecies and other plant-infecting bacterial strains (Pseudomonas syringae pv. maculicola and Erwinia carotovora subsp. carotovora). The results showed that the 'XccR5-89.2' primer pair amplified a 2,172-bp fragment specific to Xcc race 5. Moreover, they also amplified a 1,515-bp fragment for Xcc race 1 and an over 3,000-bp fragment for Xcc race 3. However, they did not amplify any fragments from the remaining Xcc races/strains, subspecies or other bacterial strains. The 'XccR5-89.2' primer pair was further PCR amplified from race-unknown Xcc strains and ICMP8 was identified as race 5 among nine race-unknown Xcc strains. Further cloning and sequencing of the bands amplified from race 5 and ICMP8 with 'XccR5-89.2' primers revealed both carrying identical sequences. The results showed that the 'XccR5-89.2' marker can effectively and proficiently detect, and identify Xcc race 5 from Xcc races/strains, subspecies and other plant-infecting bacteria. To our knowledge, this is the first report for an Xcc race 5-specific molecular marker.
\end{abstract}

Keywords: Xanthomonas campestris pv. campestris, race 5, black rot, molecular marker, cabbage

\section{Introduction}

Xanthomonas campestris pv. campestris (Pam.) Dowson $(X c c)$ is one of the most important pathogens for Brassica vegetable growing regions of the world. Xcc is a gramnegative, aerobic and rod-shaped bacterium that causes black rot. Black rot is a devastating disease of cabbage and other Brassica crops, including cauliflower, broccoli, kohlrabi, Brussels sprout, kale, mustard, turnip and turnip greens $[1,2]$. This pathogen can also infect other cruciferous vegetables, including radish and Arabidopsis as well as weeds and ornamentals [2].

The primary sources of inoculation of Xcc are infected seeds and plant residues; however, it can also survive in cruciferous weeds and ornamentals [1]. Besides infected seeds and plants, Xcc can also spread via, rain, wind, irrigation, agricultural implements, international seed trade, cruciferous weeds and non-cruciferous crops [3]. Xcc is a vascular pathogen that can enter into plants via wounds, leaf hydathodes and insects [4]. Subsequently, infection proceeds to the vascular tissue where it multiplies and develops typical V-shaped yellow lesions at the leaf borders along with necrotic and darkened veins [4-7].

Black rot disease drastically reduces the economic value of cruciferous crops. It has been reported that up to $100 \%$ of cabbage yield can be reduced by Xcc under favorable environmental conditions [4, 8]. In the Republic of Korea, heading cabbage (Brassica oleracea ssp. capitata) is the third most important Brassica vegetable and one in which black rot is also recognized as a major constraint for production [9]. 
It is very hard to control black rot with traditional disease management practices that include the use of disease-free seeds, removal of crop residues, practicing crop rotation, and the use of resistant cultivars and agrochemicals. To date, several black rot-resistant cultivars / F1/lines have been reported in different Brassica crops [1, 10-13]. However, these genotypes have not shown resistance against all the Xcc races. At present, a total of eleven physiological races of Xcc (races 1-11) has been reported by different researchers. Initially, Kamoun et al. [10] identified five different physiological races (0-4). Thereafter, Vicente et al. [1] reported six Xcc races (1-6) of Xcc. Further, three additional races $(7,8$, and 9$)$ were reported by Jensen $e$ al. [14], Fargier and Manceau [11]. Recently, two new races (10-11) were reported by Cruz et al. [12]. However, these races were identified with traditional methods based on the reactions of differential Brassica species with resistance genes with pathogens carrying avirulence genes. Among 11 races, races 1 and 4 have been reported as the most virulent throughout the world due to severe infections in B. oleracea subspecies, while race 6 is common in B. rapa [3, 15]. Moreover, the occurrence of races 5 and 6 was reported in black rot-infected fields in Nepal [14] and northwest Spain [3]. Recent studies have demonstrated that the type III secretion system (T3SS) is an essential secretion system for the virulence of the bacterial pathogens of plants and animals [16, 17]. In Xcc, the hrp (hypersensitive response and pathogenicity) gene cluster encodes a T3SS which is highly conserved and involved in pathogenicity [15]. Therefore, Zaccardelli et al. [18] developed a PCR-based molecular marker using T3SS gene $h r c C$ for detection and identification of Xcc from other $X c$ subspecies. Recent studies have revealed that type III effector genes are required for the virulence of Xcc races. For example, Jiang et al. [19] have shown that $X o p N$ is essential for full virulence of $X c c$ race 9 (strain 8004), while Ignatov et al. [20] showed that avirulence gene $\operatorname{avrRxc1/3}$ (homologue of avrBs2) determines the Xcc races.

Therefore, proper and quick race determination is essential to develop race-specific resistant cultivars against black rot. The PCR-based race detection technique has been proven as a very powerful, rapid and reliable method for Xanthomonas oryzae pv. oryzae (Xoo) and Xcc [21-23]. Thus, one of our research goals is to identify and determine the predominant Xcc races in Korea. Our research group has already developed race-specific molecular markers for Xcc race 1,3 , and $4[22,23]$ and some others are under development. Therefore, the objective of this study was to also develop a marker for rapid detection of Xcc race 5 .

\section{Materials and Methods}

\section{Bacterial Strains and Media}

A total of 24 bacterial strains including standard reference races (race 1-8) of Xanthomonas campestris pv. campestris (Xcc), Xcc strains (race undetermined), Xc subspecies, strains of other bacteria was used (Table 1). These bacterial strains were grown on 'King's Medium $B^{\prime}$ at $30^{\circ} \mathrm{C}(48 \mathrm{~h})$ [24].

\section{Extraction of Genomic DNA}

The genomic DNA (gDNA) was extracted from all the bacteria with DNeasy Plant Mini Kit (Qiagen, USA) according to the manufacturer's guidelines. The concentration and purity of the gDNA were ascertained by a NanoDrop spectrophotometer (NanoDrop Technologies, Wilmington, USA) and kept in the freezer at $-20^{\circ} \mathrm{C}$ until analyzed.

\section{Identification of Variable Genomic Region}

The whole genome sequences of Xcc races (race 1, 3, 4, and 9), Xcc strains (ICMP 4013, ICMP 21080 and Xcc strain 17) and Xc subspecies (Xci strain 'CFBP 1606R', Xcr '756C', Xcv strain '85-10' were downloaded from the NCBI (https://www.ncbi.nlm.nih. gov/genome/microbes/) (Table 2). Successively, these available whole genomes were re-aligned with the progressiveMauve tool [25]. Finally, the highly variable genomic regions were recognized by using Geneious software (trial version, www.geneious.com).

\section{PCR Analysis}

The extremely variable genomic fragment 'XccR5-89.2' was subjected to primer design (Table 3) with the help of PCR Primer Stats (http://www.bioinformatics.org/sms2/pcr_primer_stats.html). Thereafter, the specificity of the primers was tested with in silico PCR (http://insilico.ehu.es/PCR/index.php?mo=Xanthomonas). The PCR amplification was carried out using gDNA samples extracted from bacterial strains (Table 1). The PCR reaction was performed in $20 \mu \mathrm{l}$ volume, which contained $30 \mathrm{ng}$ of gDNA, 10 pmol of each forward and reverse primers, $0.25 \mathrm{mM} \mathrm{dNTP} \mathrm{mix,}$ $5 \times$ GoTaq buffer, 1 unit of GoTaq DNA Polymerase (Promega, WI, USA). The reaction condition was adjusted with a preliminary denaturation at $95^{\circ} \mathrm{C}$ for 5 min followed by 22 cycles $\left(95^{\circ} \mathrm{C}\right.$ for $30 \mathrm{sec}, 63^{\circ} \mathrm{C}$ for $40 \mathrm{sec}$, and $72^{\circ} \mathrm{C}$ for $45 \mathrm{sec}$ ) with a final extension at $72^{\circ} \mathrm{C}$ for $5 \mathrm{~min}$. The amplified PCR products were analyzed by $1.2 \%$ agarose gel electrophoresis and the bands were visualized using a gel documentation system.

\section{Cloning and Sequencing}

A genomic fragment of about $2.2 \mathrm{~kb}$ specifically amplified from Xcc race 5 with 'XccR5-89.2' primers was extracted from the agarose gel and purified by the Wizard SV Gel and PCR Cleanup system (Promega, USA). Thereafter, the purified PCR product was cloned by using TOP Cloner Blunt Kit (Enzynomics, Korea) following the manufacturer's protocol. The selected positive clones were further cultured in liquid LB media for overnight and 
Table 1. List of bacterial strains with their host used in this study.

\begin{tabular}{|c|c|c|c|c|c|}
\hline Sl. No. & Bacterial species/strains & Race & Host & Origin & Source \\
\hline 1 & Xcc (HRIW-3811) & Race 1 & B. oleracea & United States of America & HRI-W \\
\hline 2 & Xcc (HRIW-3849A) & Race 2 & Cauliflower & United States of America & \\
\hline 3 & Xcc (HRIW-5212) & Race 3 & Brussels sprout & United Kingdom & \\
\hline 4 & Xcc (HRIW-1279A) & Race 4 & Cabbage & United Kingdom & \\
\hline 5 & Xcc (HRIW-3880) & Race 5 & Cabbage & Australia & \\
\hline 6 & Xcc (HRIW-6181) & Race 6 & Chinese cabbage & Portugal (Sardoal) & \\
\hline 7 & Xcc (HRIW-8450A) & Race 7 & Cabbage & United Kingdom & \\
\hline 8 & Xcc (MBG-145.3) & Race 8 & Turnip greens & Northwestern Spain & MBG-CSIC \\
\hline 9 & Xci (HRI-W-6377) & - & Hoary stock & United Kingdom & HRI-W \\
\hline 10 & Xcr (WHRI-8305) & - & Japanese mustard spinach & United Kingdom & \\
\hline 11 & Psm (ICMP13051) & - & Cabbage & New Zealand & ICMP \\
\hline 12 & Ecc (ICMP12464) & - & Cabbage & New Zealand & \\
\hline 13 & Xcc strain (ICMP 8) & - & Cabbage & New Zealand & \\
\hline 14 & Xcc strain (KACC19132) & - & Chinese cabbage & South Korea & KACC \\
\hline 15 & Xcc strain (KACC19133) & - & Chinese cabbage & South Korea & \\
\hline 16 & Xcc strain (KACC19134) & - & Chinese cabbage & South Korea & \\
\hline 17 & Xcc strain (KACC19135) & - & - & South Korea & \\
\hline 18 & Xcc strain (KACC19136) & - & - & South Korea & \\
\hline 19 & Xcc strain (KACC17966) & - & - & South Korea & \\
\hline 20 & Xcc strain (KACC10377) & - & - & South Korea & \\
\hline 21 & Xev (KACC 11153) & - & - & South Korea & \\
\hline 22 & Xag (KACC10491) & - & Soybean & South Korea & \\
\hline 23 & Xad (KACC17821) & - & Anthurium & South Korea & \\
\hline 24 & Xcz (KACC17126) & - & Zinnia & South Korea & \\
\hline
\end{tabular}

HRI-W, Horticulture Research International, Wellesbourne, United Kingdom; ICMP, International Collection of Microorganisms from Plants, New Zealand; KACC, Korean Agricultural Culture Collection, South Korea; MBG-CSIC, Misión Biológica de Galicia, Pontevedra, Spain. Xcc, Xanthomonas campestris pv. campestris; Xcz, X. campestris pv. zinnia; Xad, X. axonopodis pv. dieffenbachiae; Xag, X. axonopodis pv. glycines; Xcv, X. campestris pv. vesicatoria; Psm, Pseudomonas syringae pv. maculicola; Ecc, Erwinia carotovora subsp. carotovora.

plasmid DNA was purified using a commercial kit (GeneAll, Korea). The purified plasmid DNA samples were sequenced by ABI 3730XL DNA Sequencer (Macrogen Inc., Korea) with universal primers. The sequence alignment was performed using Clustal Omega (https://www.ebi.ac.uk/Tools/msa/clustalo/).

Table 2. The available whole genome sequences of Xanthomonas campestris pv. campestris $(X c c)$ races, Xcc strains and Xc subspecies, and their accession number.

\begin{tabular}{|c|c|c|c|c|c|}
\hline Sl. No. & Bacterial strains & Genebank accession & Races & Genome size (bp) & References \\
\hline 1 & $\mathrm{~B} 100(\mathrm{Xcc})$ & AM920689 & 1 & $5,079,002$ & [31] \\
\hline 2 & CFBP1869 (Xcc) & NZ_CM002545 & 1 & $5,011,687$ & [32] \\
\hline 3 & Xca5 $(X c c)$ & NZ_HF570389 & 1 & $4,916,437$ & [33] \\
\hline 4 & ATCC $33913(X c c)$ & AE008922 & 3 & $5,076,187$ & [34] \\
\hline 5 & CFBP 5817 & NZ_CM002673 & 4 & $4,918,955$ & [32] \\
\hline 6 & Strain $8004(X c c)$ & NC_007086 & 9 & $5,148,708$ & [35] \\
\hline 7 & ICMP 4013 & СР012146 & - & $4,908,383$ & [36] \\
\hline 8 & ICMP $21080(X c c)$ & СР012145 & - & $4,911,121$ & [36] \\
\hline 9 & Strain $17(X c c)$ & СР011946 & - & $4,994,426$ & [37] \\
\hline 10 & CFBP 1606R (Xci) & NZ_CM002635 & - & $4,967,288$ & [38] \\
\hline 11 & Strain $756 C(X c r)$ & NC_017271 & - & $4,941,214$ & [39] \\
\hline 12 & Strain 85-10 $(X c v)$ & NC_007508 & - & $5,178,466$ & [40] \\
\hline
\end{tabular}

Xci, Xanthomonas campestris pv. incanae; Xcr, Xanthomonas campestris pv. raphani; Xcv, Xanthomonas campestris pv. vesicatoria. 
Table 3. List of primers used in this study.

\begin{tabular}{ccc}
\hline Primer name & Nucleotide sequence $\left(5^{\prime}\right.$ to $\left.3^{\prime}\right)$ & Length $(\mathrm{bp})$ \\
\hline XccR5-89.2F & GCGAGCGATTTCACCTTCAT & 1515 \\
XccR5-89.2R & AATTCGGACAACAGCGCAAT & 1515 \\
\hline
\end{tabular}

\section{Bio-PCR Assay}

The leaves of 3-week-old cabbage plants of a black rot susceptible inbred line (SCNU-C-3328) were inoculated with Xcc races (races 1-8) following the method as previously described by Afrin et al. [23] by clipping secondary veins followed by dipping into a bacterial suspension $\left(10^{9} \mathrm{CFU} / \mathrm{ml}\right)$ and maintaining high humidity [1]. About 1-cm infected leaves were collected when black rot symptoms were visible and cut into small pieces and soaked in sterile water $(250 \mu \mathrm{l})$ for $40 \mathrm{~min}$ at room temperature. Thereafter, $10-\mu l$ exudates were directly used as a template for the bio-PCR amplification.

\section{Results}

\section{Development of Xcc Race 5-Specific Molecular Markers}

Up until now, the whole genome sequences of only four Xcc races (races 1, 3, 4, and 9), some Xcc strains (raceunspecified), and a few Xc subspecies have been reported (Table 2). Realignment of these available whole genomes permits us to find similarities (boxes have the same colors)

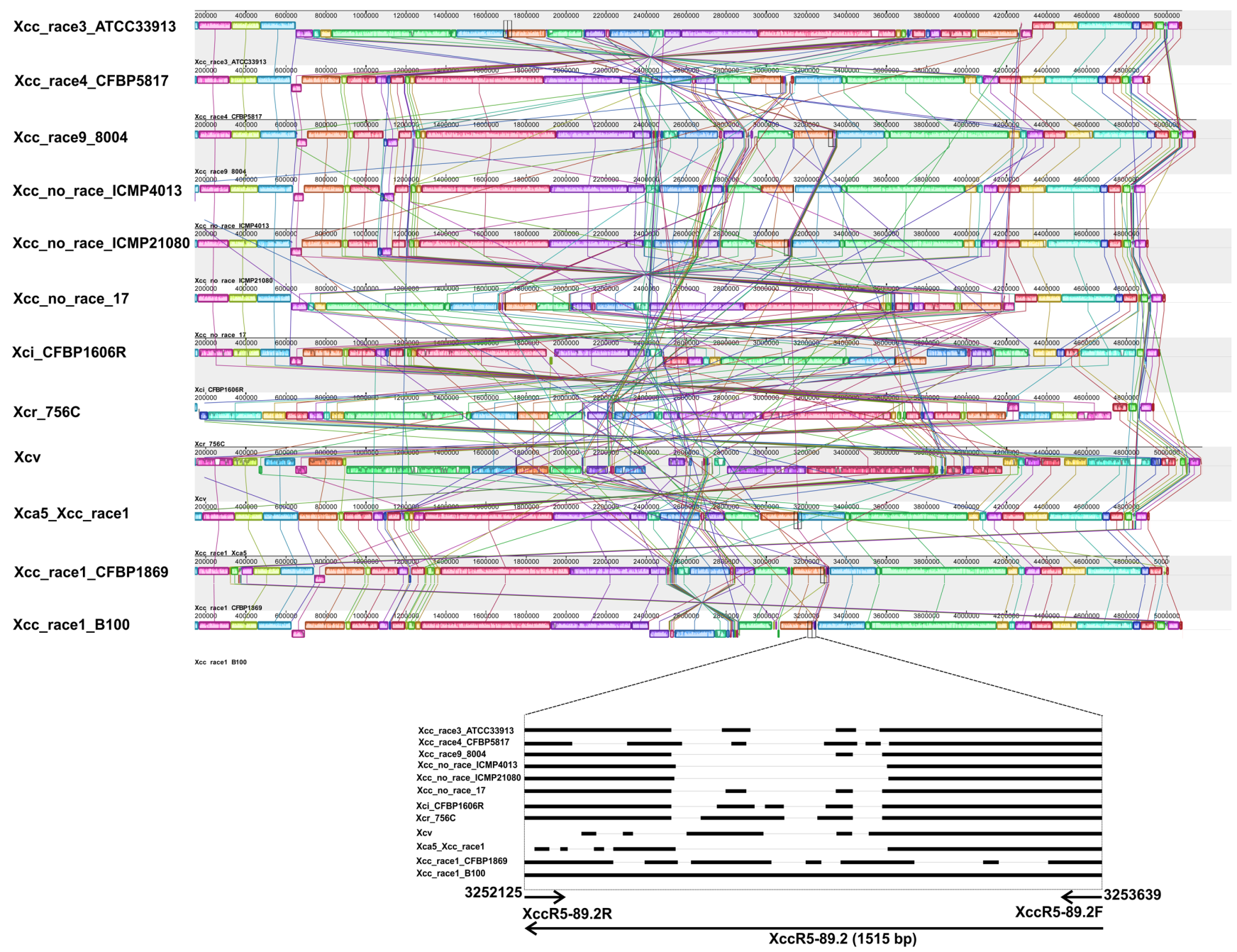

Fig. 1. Mauve alignment of the available whole genome sequences of Xanthomonas campestris pv. campestris (Xcc) races (races 1, 3, 4, and 9), strains and other subspecies of Xanthomonas campestris.

The syntenic blocks are connected among the Xcc races/strains/Xc subspecies. The highly variable regions among the Xcc races/strains/Xc subspecies are shown with the line diagram at the bottom of the alignment. The detailed descriptions and genebank accessions are provided in Table 1. Genomic blocks are shown as colored boxes. 


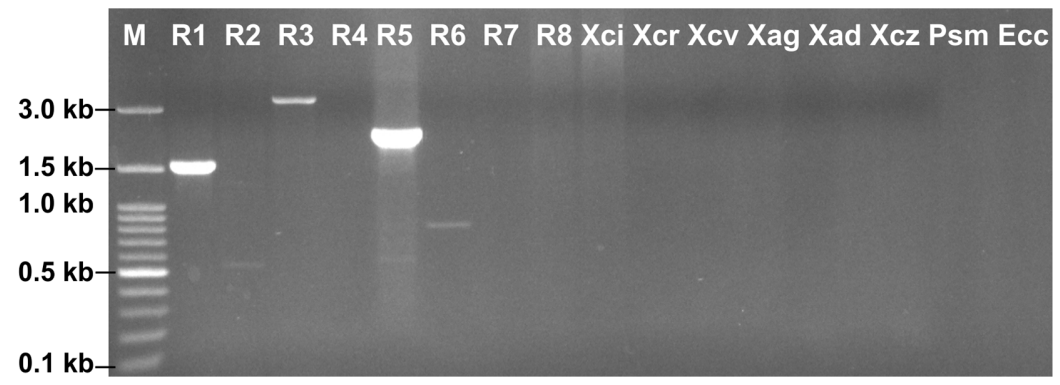

Fig. 2. Agarose gel electrophoresis of the Xcc race 5-specific XccR5-89.2 PCR products $(2,172 \mathrm{bp})$ amplified from genomic DNA of Xanthomonas campestris pv. campestris (Xcc) races and other subspecies of Xanthomonas campestris.

Lane M: 100 bp plus DNA ladder; lanes 1-8: Xcc races 1-8; lane Xci: X. campestris pv. incane (Xci); lane Xcr: X. campestris pv. raphani (Xcr); lane Xcv: X. campestris pv. vesicatoria (Xcv); lane Xag: X. axonopodis pv. glycines (Xag); lane Xad: X. axonopodis pv. dieffenbachiae (Xad); lane Xcz: X. campestris pv. zinniae (Xcz); lane Psm: Pseudomonas syringae pv. maculicola (Psm); lane Ecc: Erwinia carotovora subsp. carotovora (Ecc).

and variabilities among the aligned genomes (Fig. 1). Since the genome of $X c c$ race 5 was not yet sequenced, hence, to develop a race 5 -specific molecular marker, we looked for the highly variable genomic regions among the 12 realigned genomes and identified the variable genomic fragment 'XccR5-89.2' (Fig. 1). Thereafter, primers were designed based on the 'XccR5-89.2' fragment from Xcc race 1 (strain B100) sequence. The PCR results showed that the 'XccR5-89.2' primers amplified an approximately 2,200-bp fragment specific to $X c c$ race 5 as well as a 1,515-bp and an over 3,000-bp fragment for race 1 and race 3, respectively (Fig. 2). Even though very faint bands were detected with $X c c$ race 2 and race 6 , the band was stronger when race 5 was present. However, there was no amplicon detected for the remaining Xcc races, subspecies or other-plant infecting bacteria tested in this study. Furthermore, the fragment amplified from Xcc race 5 was cloned and sequenced. Since

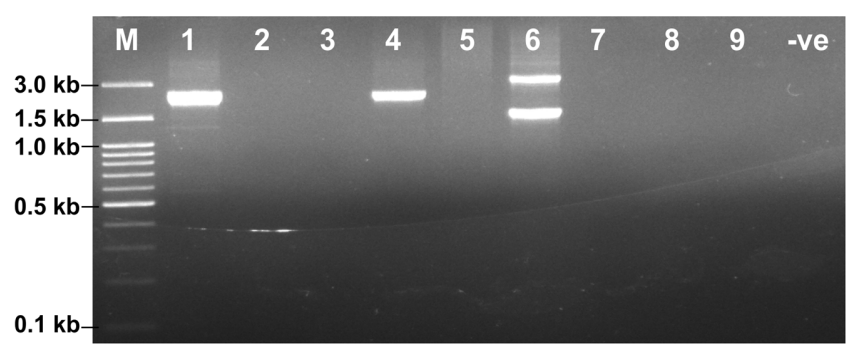

Fig. 3. PCR amplification Xanthomonas campestris pv. campestris $(\mathrm{Xcc}$ ) race 5 specific XccR5-89.2 primers from raceunknown Xcc strains for race determination.

Lane M: 100 bp plus DNA ladder; lane 1: Xcc race 5 (HRIW-3880) as positive control; lanes 2-9: Xcc race unknown strains (KACC19132, KACC19133, ICMP 8, KACC17966, KACC10377, KACC19134, KACC19135 and KACC19136); lane -ve: negative control. the size of the cloned fragment was around $2.2-\mathrm{kb}$, hence, with the universal primers, we found only a part of both the 5'and 3 'ends of the sequence. Consequently, we performed primer walking to cover the full sequence (Fig. S1). The sequence analysis revealed that fragment amplified from race 5 was 2,172-bp (Fig. S2).

The 2,172-bp nucleotide sequence obtained through cloning and sequencing of the 'XccR5-89.2' fragment from $X c c$ race 5 was subjected to ORF prediction using the ORF Finder in the NCBI (https://www.ncbi.nlm.nih.gov/ orffinder/) (Fig. 4). The result showed that the longest ORF (negative strand) was 990-bp (329-aa residues) (Fig. S3). Furthermore, the BLASTP was accomplished against the NCBI and found that it has significant homology with the protein encoding an IS4 family transposase of Xanthomonas campestris (WP_011038666.1).

\section{Race Determination for Race Unknown Xcc Strains}

The 'XccR5-89.2' primer pair was further used to find the race information of eight race-unknown Xcc strains (Table 2). The PCR result showed that this primer pair specifically amplified a 2,200-bp fragment similar to Xcc race 5 from Xcc strain ICMP 8 (Fig. 3). As regards Xcc strain KACC10377, it amplified two fragments (about 1,500-bp and 3,000-bp) while the remaining six unknown strains did not show any amplification.

\section{Detection of Xcc Race 5 from Infected Cabbage Leaves}

The potentiality of race 5 -specific primers was determined by bio-PCR with artificially inoculated cabbage leaves with different Xcc races (races 1-8). The results revealed that only cabbage samples inoculated with race 5 were amplified while no visible bands were detected in the remaining 21 samples inoculated with other Xcc races (Fig. 6). 


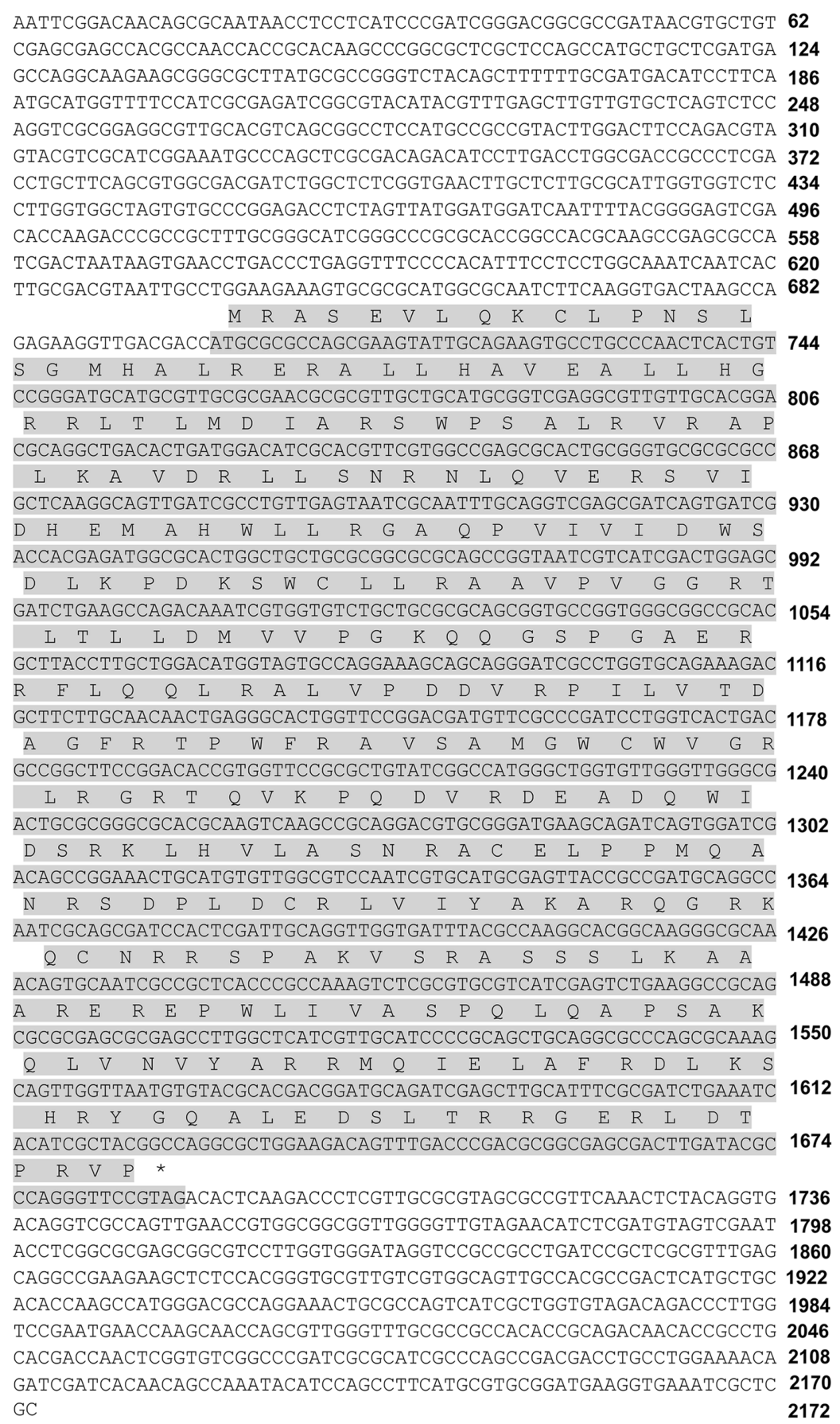

Fig. 4. Nucleotide and amino acid sequences of the XccR5-89.2 fragment cloned and sequenced from Xanthomonas campestris pv. campestris race 5 .

A 990-bp ORF is shown in the grey highlighted area. The deduced amino acid sequence (329 aa) is shown in the above of the nucleotide sequence. The nucleotide sequence is shown as reverse complement.

\section{Discussion}

Black rot disease is one of the major constraints of Brassica vegetables including cabbage which causes substantial yield loss throughout the world. So far, a total of eleven physiological races of $X c c$, the pathogen of black rot disease have been reported [1, 10-12]. Moreover, Afrin et al. [13] have reported some black rot disease-resistant cabbage 
lines, nonetheless, they showed Xcc race-specific resistance. Thus, proper detection of $X c c$ races is crucial to manage this disease and to understand its occurrence and evolution. Recently, race-specific molecular markers for detection of $X c c$ race 1, race 3 and race 4 have been reported [22, 23]. The complete genome sequence of some Xcc races/strains and subspecies opened the avenue for comparative genome analysis which facilitates us in finding out highly specific and variable genomic regions (Table 2 and Fig. 1).

We developed a molecular marker for rapid, reliable, specific and effective detection of Xcc race 5. This marker can specifically and effectively detect and distinguish Xcc race 5 among the $X c c$ races/strains, $X c$ subspecies and other plant-infecting bacteria (Figs. 2 and 3). This molecular marker based-PCR detection method is simple, inexpensive, reliable and rapid as compared to the traditional race determination techniques which are very expensive and time consuming. The molecular marker-based pathogen detection technique has successfully been used to identify plant-infecting bacterial and fungal pathogens. Rubel et al. [22] reported molecular markers (InDel and SCAR) for detection of $X c c$ race 1 and race 4 , the pathogen of black rot disease. Later, Afrin et al. [23] also reported molecular markers (InDel and SCAR) for detection of Xcc race 3. These molecular markers can quickly and effectively detect $X c c$ races and even from directly infected plants with bioPCR. Song et al. [21] developed a SCAR marker for specific detection of Xanthomonas oryzae pv. oryzae (Xoo) race K3a, the causal agent of bacterial blight of rice. A SCAR marker has been reported by Luongo et al. [26] to detect the fungal pathogen, Fusarium oxysporum f. sp. melonis race 2, which causes vascular wilt of cucurbits. Similarly, Lin et al. [27] demonstrated PCR-based molecular marker 'Foc-1/Foc-2' which can easily identify Fusarium oxysporum f. sp. cubense race 4 , the pathogen of the panama disease of banana. Two SCAR markers have also been reported for detecting

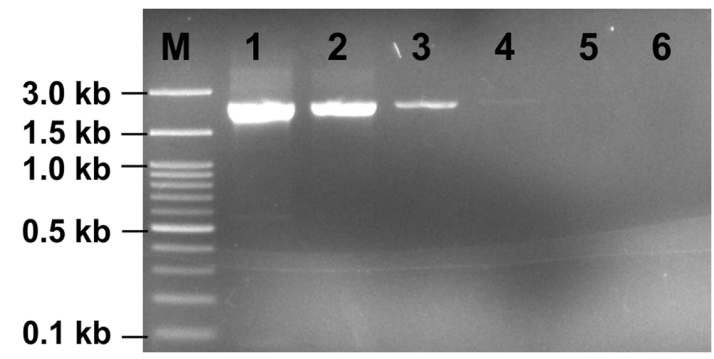

Fig. 5. Limits of detection of Xcc race 5 from genomic DNA by XccR5-89.2 primers.

Lane M: DNA ladder; lane 1, $50 \mathrm{ng} / \mu \mathrm{l}$ gDNA; lane 2, $5 \mathrm{ng} / \mu \mathrm{l}$; lane 3, $0.5 \mathrm{ng} / \mu \mathrm{l}$; lane 4, $0.05 \mathrm{ng} / \mu \mathrm{l}$; lane 5, $0.005 \mathrm{ng} / \mu \mathrm{l}$; lane 6 , negative control. For the PCR amplification, $1 \mu \mathrm{l}$ DNA of Xcc race 5 from each dilutions was used as a template.

Chinese races (CYR32 and CYR33) Puccinia striiformis f. sp. tritici, the pathogen of stripe rust disease in wheat [28].

The 'XccR5-89.2' marker amplified a similar specific fragment as Xcc race 5 from the Xcc race-unknown strain ICMP 8 suggesting that it might belong to race 5 (Fig. 3). Moreover, we confirmed this via cloning and sequencing of the band amplified from ICMP8 with the 'XccR589.2' primers. The sequence analysis revealed that the amplified band from ICMP8 was 100\% identical to the 'XccR5-89.2' genomic fragment of Xcc race 5 (Fig. S2). Rubel et al. [22] developed 'Xcc_47R1' and 'Xcc_85R1' markers with a similar technique and demonstrated that those markers can distinguish race 1 from race-unknown Xcc strains.

It has been reported that insertion sequences (IS) and transposons are playing a major role in bacterial pathogenicity and evolution including Xanthomonads via the genome rearrangement [29]. The sequence analysis of the 'XccR589.2' fragment revealed that it has a 990-bp ORF which showed $100 \%$ identity with IS4 family transposase of Xanthomonas campestris. Further, conserved domain analysis of the protein sequence (329-aa) identified the existence of

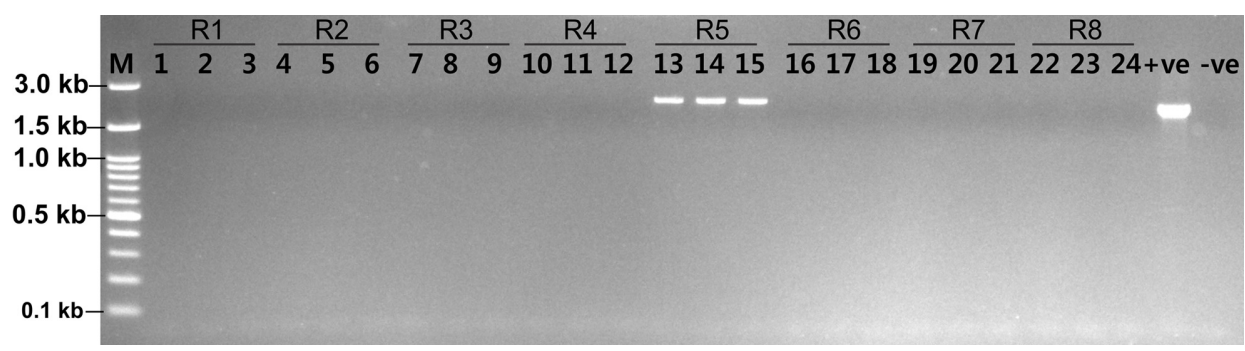

Fig. 6. Detection of Xcc race 5 by bio-PCR with artificially Xcc (races 1-8, R1-R8) inoculated cabbage leaves with XccR5-89.2 primers.

Lanes 1-24, artificially inoculated leaf samples with Xcc races (lanes 1-3, race 1; lanes 4-6, race 2; lanes 7-9, race 3; lanes 10-12, race 4; lanes 13-15, race 5; lanes 16-18, race 6; lanes 19-21, race 7; +ve, gDNA of Xcc race 5 as a positive control; -ve, negative control; M, DNA ladder). 
transposase DDE domain (DDE_Tnp_1) (Fig. S3). This DDE_Tnp_1 domain is essential for effective DNA transposition [30]. This result suggests that this IS4 family transposase might have a role in the race diversity of Xcc.

The 'XccR5-89.2' primers can detect Xcc race 5 from a very small quantity of gDNA by PCR amplification indicating the higher sensitivity of the marker (Fig. 5). The novel 'XccR5-89.2' marker developed through this study provids an effective, specific, rapid, easy and powerful tool for detection of race 5 from other Xcc races/strains throughout the world.

Recently, a PCR-based technique named as bio-PCR has been shown as an effective method of detecting and identifying plant pathogens, including Xcc and Xoo directly from infected samples [21-23]. We also applied a similar bio-PCR assay in our study and race 5-specific 'XccR5-89.2' primers simply and efficiently detected and recognized Xcc race 5 directly from diseased cabbage leaves (Fig. 6). Therefore, this marker might be convenient for quick detection of Xcc race 5 from black rot infected cabbage leaves directly from farmers' fields.

In this study, we developed a molecular marker (XccR589.2) specific to $\mathrm{Xcc}$ race 5 through the realignment of whole genome sequences of 12 bacterial strains including $X c c$ races/strains and subspecies. This novel 'XccR5-89.2' marker detected Xcc race 5 from other Xcc races/strains/ subspecies by PCR quickly with high reliability and sensitivity. To the best of our knowledge, this is the first report for an Xcc race 5-specific marker that could be useful for simple, rapid and effective detection of black rot disease at an earlier stage of its development throughout the world.

\section{Acknowledgments}

This research work was supported by the Golden Seed Project (Center for Horticultural Seed Development) of the Ministry of Agriculture, Food and Rural Affairs in the Republic of Korea (MAFRA) under Grant no. 213007-05-3CG100. We thank Dr Joana G. Vicente, University of Warwick, UK for providing Xcc races (races 1-7). We also thank Dr Pilar Soengas, Department of Plant Genetics, Misión Biológica de Galicia (MBG-CSIC), Pontevedra, Spain for providing Xcc race 8. We thank Dr Sathishkumar Natarajan for the design of primers.

\section{Conflict of Interest}

The authors have no financial conflicts of interest to declare.

\section{Reference}

1. Vicente JG, Conway J, Roberts SJ, Taylor JD. 2001. Identification and origin of Xanthomonas campestris pv. campestris races and related pathovars. Phytopathology 91: 492-499.

2. Soengas P, Hand P, Vicente JG, Pole JM, Pink DAC. 2007. Identification of quantitative trait loci for resistance to Xanthomonas campestris pv. campestris in Brassica rapa. Theor. Appl. Genet. 114: 637-645.

3. Lema M, Cartea ME, Sotelo T, Velasco P, Soengas P. 2012. Discrimination of Xanthomonas campestris pv. campestris races among strains from northwestern Spain by Brassica spp. genotypes and rep-PCR. Eur. J. Plant Pathol. 133: 159-169.

4. Williams PH. 1980. Black rot: a continuing threat to world crucifers. Plant Dis. 64: 736-742.

5. Cook AA, Walker JC, Larson RH. 1952. Studies on the disease cycle of black rot of crucifers. Phytopathology 42: 162-167.

6. Kifuji Y, Hanzawa H, Terasawa Y, Ashutosh, Nishio T. 2013. QTL analysis of black rot resistance in cabbage using newly developed EST-SNP markers. Euphytica 190: 289-295.

7. Tonu NN, Shimizu M, Karim MM, Kawanabe T, Fujimoto $\mathrm{R}$, Okazaki K, et al. 2013. Comparison of positions of QTLs conferring resistance to Xanthomonas campestris pv. campestris in Brassica oleracea. Am. J. Plant Sci. 4: 11-20.

8. Massomo SMS, Nielsen H, Mabagala RB, Mansfeld-Giese K, Hockenhull J, Mortensen CN. 2003. Identification and characterisation of Xanthomonas campestris pv. campestris strains from Tanzania by pathogenicity tests, biolog, repPCR and fatty acid methyl ester analysis. Eur. J. Plant Pathol. 109: 775-789.

9. Kim B. 1986. Testing for detection of Xanthomonas campestris pv. campestris in crucifer seeds and seed disinfection. Korean J. Plant Pathol. 2: 96-101.

10. Kamoun S, Kamdar HV, Tola E, Kado CI. 1992. Incompatible interactions between Crucifers and Xanthomonas campestris involve a vascular hypersensitive response: role of the $h r p K$ locus. Mol. Plant-Microbe Interact. 5: 22-33.

11. Fargier E, Manceau C. 2007. Pathogenicity assays restrict the species Xanthomonas campestris into three pathovars and reveal nine races within $X$. campestris pv. campestris. Plant Pathol. 56: 805-818.

12. Cruz J, Tenreiro R, Cruz L. 2017. Assessment of diversity of Xanthomonas campestris pathovars affecting cruciferous plants in Portugal and disclosure of two novel X. campestris pv. campestris races. J. Plant Pathol. 99: 403-414.

13. Afrin KS, Rahim MA, Park JI, Natarajan S, Rubel MH, Kim HT, et al. 2018. Screening of cabbage (Brassica oleracea L.) germplasm for resistance to black rot. Plant Breed. Biotechnol. 6: 30-43.

14. Jensen BD, Vicente JG, Manandhar HK, Roberts SJ. 2010. Occurrence and diversity of Xanthomonas campestris pv. campestris in vegetable Brassica fields in Nepal. Plant Dis. 94: 298-305. 
15. Vicente JG, Holub EB. 2013. Xanthomonas campestris pv. campestris (cause of black rot of crucifers) in the genomic era is still a worldwide threat to brassica crops. Mol. Plant Pathol. 14: 2-18.

16. Galán J, Collmer A. 1999. Type III secretion machines: bacterial devices for protein delivery into host cells. Science 284: 1322-1328.

17. Buttner D, He SY. 2009. Type III protein secretion in plant pathogenic bacteria. Plant Physiol. 150: 1656-1664.

18. Zaccardelli M, Campanile F, Spasiano A, Merighi M. 2007. Detection and identification of the crucifer pathogen, Xanthomonas campestris pv. campestris, by PCR amplification of the conserved Hrp/type III secretion system gene hrcC. Eur. J. Plant Pathol. 118: 299-306.

19. Jiang BL, He YQ, Cen WJ, Wei HY, Jiang GF, Jiang W, et al. 2008. The type III secretion effector xopXccN of Xanthomonas campestris pv. campestris is required for full virulence. Res. Microbiol. 159: 216-220.

20. Ignatov AN, Monakhos GF, Djalilov FS, Pozmogova GV. 2002. Avirulence gene from Xanthomonas campestris pv. campestris homologous to the avrBs2 locus is recognized in race-specific reaction by two different resistance genes in brassicas. Russ. J. Genet. 38: 1404-1410.

21. Song ES, Kim SY, Noh TH, Cho H, Chae SC, Lee BM. 2014. PCR-based assay for rapid and specific detection of the new Xanthomonas oryzae pv. oryzae K3a race using an AFLPderived marker. J. Microbiol. Biotechnol. 24: 732-739.

22. Rubel MH, Robin AHK, Natarajan S, Vicente JG, Kim HT, Park JI, et al. 2017. Whole-genome re-alignment facilitates development of specific molecular markers for races 1 and 4 of Xanthomonas campestris pv. campestris, the cause of black rot disease in Brassica oleracea. Int. J. Mol. Sci. 18(12) pii: E2523.

23. Afrin KS, Rahim MA, Rubel MH, Natarajan S, Song JY, Kim HT, et al. 2018. Development of race-specific molecular marker for Xanthomonas campestris pv. campestris race 3, the causal agent of black rot of crucifers. Can. J. Plant Sci. 98: 1119-1125.

24. King EO, Ward MK, Raney DE. 1954. Two simple media for the demonstration of pyocyanin and fluorescin. J. Lab. Clin. Med. 44: 301-3.7.

25. Darling ACE, Mau B, Blattner FR, Perna NT. 2004. Mauve: multiple alignment of conserved genomic sequence with rearrangements. Genome Res. 14: 1394-1403.

26. Luongo L, Vitale S, Haegi A, Belisario A. 2012. Development of SCAR markers and PCR assays for Fusarium oxysporum $\mathrm{f}$. sp. melonis race 2 specific detection. J. Plant Pathol. 94: 193-199.

27. Lin YH, Chang JY, Liu ET, Chao CP, Huang JW, Chang PFL.2009. Development of a molecular marker for specific detection of Fusarium oxysporum f. sp. cubense race 4. Eur. J. Plant Pathol. 123: 353-365.
28. Wang BT, Hu XP, Li Q, Hao BJ, Zhang B, Li GB, et al. Development of race-specific SCAR markers for detection of Chinese races CYR32 and CYR33 of Puccinia striiformis f. sp. tritici. Plant Dis. 94: 221-228.

29. Ferreira RM, de Oliveira ACP, Moreira LM, Belasque J, Gourbeyre E, Siguier P, et al. 2015. A TALE of Transposition: Tn3-like transposons play a major role in the spread of pathogenicity determinants of Xanthomonas citri and other xanthomonads. MBio 6: e02505-14.

30. Klaer R, Kühn S, Tillmann E, Fritz H-J, Starlinger P. 1981. The sequence of IS4. Mol. Gen. Genet. 181: 169-175.

31. Vorhölter FJ, Schneiker S, Goesmann A, Krause L, Bekel T, Kaiser O, et al. 2008. The genome of Xanthomonas campestris pv. campestris B100 and its use for the reconstruction of metabolic pathways involved in xanthan biosynthesis. J. Biotechnol. 134: 33-45.

32. Bolot $S$, Cerutti A, Carrère $S$, Arlat $M$, Fischer-Le Saux $M$, Portier P, et al. 2015. Genome sequences of the race 1 and race 4 Xanthomonas campestris pv. campestris strains CFBP 1869 and CFBP 5817. Genome Announc. 3: e01023-15.

33. Bolot S, Guy E, Carrere S, Barbe V, Arlat M, Noël LD. 2013. Genome sequence of Xanthomonas campestris pv. campestris strain Xca5. Genome Announc. 1: e00032-12.

34. da Silva ACR, Ferro JA, Reinach FC, Farah CS, Furlan LR, Quaggio RB, et al. 2002. Comparison of the genomes of two Xanthomonas pathogens with differing host specificities. Nature 417: 459-463.

35. Qian W, Jia Y, Ren S, He Y, Feng J, Lu L, et al. 2005. Comparative and functional genomic analyses of the pathogenicity of phytopathogen. Genome Res. 15: 757-767.

36. Desai D, Li J-H, van Zijll de Jong E, Braun R, Pitman A, Visnovsky S, et al. 2015. Draft genome sequences of two New Zealand Xanthomonas campestris pv. campestris isolates, ICMP 4013 and ICMP 21080. Genome Announc. 3: e01247-15.

37. Liu YC, Wang SC, Yu YJ, Fung KM, Yang MT, Tseng YH, et al. 2015. Complete genome sequence of Xanthomonas campestris pv. campestris strain 17 from Taiwan. Genome Announc. 3: e01466-15.

38. Roux B, Bolot S, Guy E, Denancé N, Lautier M, Jardinaud M-F, et al. 2015. Genomics and transcriptomics of Xanthomonas campestris species challenge the concept of core type III effectome. BMC Genomics 16: 975.

39. Bogdanove AJ, Koebnik R, Lu H, Furutani A, Angiuoli S V, Patil PB, et al. 2011. Two new complete genome sequences offer insight into host and tissue specificity of plant pathogenic Xanthomonas spp. J. Bacteriol. 193: 5450-5464.

40. Thieme F, Koebnik R, Bekel T, Berger C, Boch J, Büttner D, et al. 2005. Insights into genome plasticity and pathogenicity of the plant pathogenic bacterium Xanthomonas campestris pv. vesicatoria revealed by the complete genome sequence. $J$. Bacteriol. 187: 7254-7266. 